Sugerowane cytowanie:

Jonek-Kowalska, I. (2020). Finansowanie podmiotów ekonomii społecznej a rozwój przedsiębiorczości społecznej w Polsce. Wnioski sprzed kryzysu wywołanego przez COVID-19 i refleksje pokryzysowe.

W: M. Ćwiklicki, K. Sienkiewicz-Małyjurek, (red.). Ekonomia Społeczna. Przedsiębiorczość społeczna w czasie kryzysu (s. 78-91). Kraków: Uniwersytet Ekonomiczny w Krakowie. https://doi.org/10.15678/ES.2020.2.07

\title{
Finansowanie podmiotów ekonomii społecznej a rozwój przedsiębiorczości społecznej w Polsce. Wnioski sprzed kryzysu wywołanego przez COVID-19 i refleksje pokryzysowe
}

\section{Izabela Jonek-Kowalska}

Streszczenie: Rozwój przedsiębiorczości społecznej wiąże się z wieloma barierami o zróżnicowanym charakterze. Jedną z najpoważniejszych jest brak środków finansowych, co staje się szczególnie odczuwalne i dokuczliwe w okresie kryzysu gospodarczego. Mając na uwadze powyższe okoliczności, głównym celem prowadzonych rozważań i badań jest analiza źródeł finansowania podmiotów ekonomii społecznej w Polsce z perspektywy historycznej i prognostycznej (w kontekście kryzysu gospodarczego wywołanego pandemią COVID-19) oraz ocena możliwości rozwojowych tych podmiotów w fazie pokryzysowej. Do zrealizowania tak postawionego celu w artykule wykorzystano analizę statystyczną danych na temat źródeł finansowania podmiotów ekonomii społecznej w Polsce. Z przeprowadzonych analiz wynika, że w ujęciu historycznym przedsiębiorczość społeczna w Polsce rozwijała się systematyczne, aczkolwiek wolno. Świadczy o tym rosnąca liczba podmiotów działających w sferze ekonomii społecznej, w tym przede wszystkim stowarzyszeń i fundacji. Rozwój ten jest jednak aktualnie zagrożony z uwagi na zmniejszenie dochodów w sferze publicznej stanowiących główne źródło utrzymania badanych organizacji. Problemem w najbliższej przyszłości może być także pozyskiwanie składek członkowskich będących uzupełniającym źródłem finansowania przedsiębiorczości społecznej.

Słowa kluczowe: przedsiębiorczość społeczna; ekonomia społeczna; finasowanie przedsiębiorczości społecznej Kody JEL: $\mathrm{H} 00, \mathrm{~A} 32, \mathrm{~A} 13$

\section{Wstęp}

Rozwój przedsiębiorczości społecznej jest uzależniony od wielu bardzo różnorodnych determinant $\mathrm{i}$ jest analizowany $w$ literaturze przedmiotu $z$ wielu różnych perspektyw. W obszarze nauk o zarządzaniu za jedną z kluczowych stymulant przedsiębiorczości społecznej uważa się postawy zarządzających, hierarchię wyznawanych przez nich wartości oraz kreatywność i innowacyjność (Romanowska, 2016; Bartkowski, 2014). Wykorzystanie wymienionych czynników musi być ukierunkowane na działania o charakterze non-profit, które przynosi przede wszystkim korzyść społeczną (Defourny i Nyssens, 2010; Kerlin 2006). Z punktu widzenia homo oeconomicus oraz komercjalizacji współczesnego świata jest to bardzo trudnym i mało popularnym wyzwaniem. 
Poza zarządzającymi, którzy inicjują działalność podmiotów ekonomii społecznej (Hausner i in., 2008; Leś, 2005), w rozwoju przedsiębiorczości społecznej dużą rolę odgrywają indywidualne determinanty etyczne i moralne oraz czynniki kulturowe wpływające na wolę i poziom zaangażowania w samopomoc społeczną. W tym kontekście nie mniej istotne jest także zapotrzebowanie na tego typu działalność oraz jej postrzeganie w otoczeniu społeczno-gospodarczym, co w dużej mierze uzależnione jest od poziomu rozwoju gospodarczego i cywilizacyjnego danego regionu (Goyal, 2020).

Przechodząc do uszczegółowienia prezentowanej problematyki należy podkreślić, że w literaturze przedmiotu ekonomia społeczna jest definiowana w sposób różnorodny i wielowymiarowy (Łojko, 2017). Często też jest utożsamiana z przedsiębiorczością społeczną, co sprawia, że pojęcia te są używane zamiennie. W niniejszym artykule przyjęto, zgodnie z propozycją J. Hausnera, że ekonomia społeczna jest sektorem obejmującym podmioty działające w trójkącie państwo-rynek-społeczeństwo obywatelskie, a jej funkcje są komplementarne w stosunku do rynku i państwa (Płonka, 2015; Hausner, 2008). Dodatkowo założono także, że przedsiębiorczość społeczna jest ściśle powiązana z powstaniem i rozwojem tego sektora, ale ma wymiar czynnościowy i aktywizujący do:

- poszukiwania alternatywnych metod finansowania inicjatyw non-profit lub programów generujących wartość społeczną,

- podejmowania praktyk z zakresu biznesu zaangażowanego społecznie,

- łagodzenia problemów społecznych i katalizowania zmian społecznych (Pacut, 2010).

W sektorze ekonomii społecznej wyżej wymienione działania podejmują skonkretyzowane podmioty o bardzo zróżnicowanych formach organizacyjno-prawnych uzależnionych w dużej mierze od przyjętych na danym obszarze przepisów regulujących ich tworzenie i funkcjonowanie. Z tej też przyczyny można jedynie wskazywać wspólne cechy wyróżniające podmioty ekonomii społecznej, do których zalicza się sprzede wszystkim: przynoszenie korzyści społecznych, demokratyczny styl zarządzania, włączenie odbiorców w działalność i zaangażowanie władz publicznych (Mair i Martí, 2006). W praktyce, w procesie systematyzacji i charakterystyce działalności podmiotów ekonomii społecznej można wykorzystać podejście instytucjonalno-prawne, które proponuje dostępne ustawodawstwo lub/i statystyka publiczna' (Rechulicz, 2006; Płonka, 2010).

Znaczna część analiz i spostrzeżeń dotyczących samej działalności podmiotów ekonomii społecznej koncentruje się na indywidualnych i zbiorowych pożytkach wynikających z podejmowanych przez nie działalności. Eksponuje się w nich innowacyjny (Kaufman i in., 2007, 2015; Tarkowski, 2020), a zarazem charytatywny, ludzki i szlachetny wymiar tej aktywności, abstrahując niejako od konieczności zapewnienia jej odpowiednich źródeł finansowania. Tymczasem przedsiębiorcy społeczni nie są nastawieni na osiąganie zysków ekonomicznych, co pozbawia ich kluczowego czynnika rozwoju typowego dla przedsiębiorstw działających w sferze komercyjnej. Dlatego też w niniejszym rozdziale podejmuje się kwestie finansowania podmiotów ekonomii społecznej w Polsce w perspektywie ex post, bazującej na historycznych danych statystycznych oraz w perspektywie ex ante, w kontekście ogólnoświatowego kryzysu gospodarczego wywołanego pandemią wirusa COVID-19.

Badania tego typu są stosunkowo rzadko podejmowane w literaturze przedmiotu, a kwestia finansowania przedsiębiorczości społecznej opisywana jest najczęściej w kontekście barier

Takie podejście do kategoryzacji podmiotów ekonomii społecznej zastosowano w niniejszym artykule, wykorzystując do opisu ich działalności wykazy statystyczne dla tego sektora publikowane przez Główny Urząd Statystyczny. 
jej rozwoju. Warto jednak zauważyć, że z badań tych wynika, że kwestie finansowe wywierają istotny wpływ na powstawanie i rozwój podmiotów ekonomii społecznej. Gramescu (2016) badając Building a European Network of Incubators for Social Innovation (BENISI) odkrył, że duża część innowacyjnych inkubatorów przedsiębiorczości społecznej szybko znika z rynku, gdy tylko zgromadzi wystarczająco dużo wiedzy i pomysłów przenosząc się do sektora komercyjnego. Z jego badań wynika także, że przedsiębiorczość społeczna zdecydowanie lepiej rozwija się w krajach o wysokim poziomie dochodu narodowego takich jak: Dania, Norwegia, Szwecja czy Szwajcaria, niż w krajach postkomunistycznych, znajdujących się w gorszej sytuacji ekonomicznej, takich jak: Polska, Rumunia, Serbia, Chorwacja, Estonia czy Słowenia. W rozwoju przedsiębiorczości społecznej lepiej sprawdza się także wykorzystanie partnerstwa publiczno-prywatnego, dodatkowo zasilającego finansowo podmioty ekonomii społecznej, niż samodzielne, wyłącznie społeczne, funkcjonowanie i finansowanie tych organizacji (Gabriel, 2014; Weber i in., 2012). Hybrydowe źródła finansowania, w których łączy się środki publiczne i prywatne są ważną determinantą rozwoju podmiotów ekonomii społecznej, ponieważ w wielu przypadkach społeczne fundusze nie są w stanie zapewnić zrównoważonego i intensywnego rozwoju społecznej innowacyjności i przedsiębiorczości (Vanderhoven i in., 2020).

Istotność finansowania w rozwoju ekonomii społecznej wynika także z badań przeprowadzanych w Polsce. W ankiecie przeprowadzonej w 2018 roku przez Ministerstwo Rodziny, Pracy i Polityki Społecznej, aż 86\% przebadanych przedsiębiorstw społecznych wskazało, że w ciągu najbliższych 12 miesięcy będzie potrzebowało dodatkowych środków finansowych na prowadzenie działalności bieżącej i rozwojowej. Podmioty te mają jednak bardzo ograniczone możliwości dywersyfikacji zewnętrznych źródeł finansowania i najczęściej pozyskują je w formie dotacji z: Europejskiego Funduszu Społecznego, Funduszu Pracy czy PFRON lub pożyczki z Krajowego Funduszu Przedsiębiorczości Społecznej (Ekonomia społeczna w Polsce w nowej perspektywie finansowej 2020+. Wnioski i rekomendowane rozwiqzania).

Wnioski wynikające z bardziej szczegółowej analizy źródeł finansowania społecznej sfery gospodarczej dostarczają podstaw do wnikliwszej oceny jej możliwości rozwojowych, w tym także tych dotyczących funkcjonowania w fazach kryzysowej i pokryzysowej (Zioło, 2013; Sienkiewicz-Małyjurek, 2015). Są one istotne także z praktycznego punkt widzenia, ponieważz badań Głównego Urzędu Statystycznego wynika, że trudności w pozyskiwaniu środków finansowych są jedną z najpoważniejszych barier rozwojowych dla podmiotów ekonomii społecznej w Polsce (rys. 1). Poważne utrudnienie stanowi również niewystarczająca liczba chętnych do pracy, co eksponuje podażowe determinanty przedsiębiorczości społecznej. Dodatkowo, respondenci badań GUS stwierdzają też, że ich działalność komplikują problemy wynikające z przepisów i procedur prawnych.

Tymczasem współczesna ekonomia społeczna stawia przed przedsiębiorstwami społecznymi coraz to nowe wyzwania i oczekiwania związane między innymi z nieefektywnym funkcjonowaniem rynku pracy, postępującą globalizacją czy niewydolnością państwa w sprawach społecznych. Wyzwaniom tym trudno sprostać bez odpowiedniego zaplecza finansowego, dlatego też w literaturze i praktyce postuluje się podejmowanie działań na rzecz zwiększania możliwości zaspokajania potrzeb kapitałowych przedsiębiorstw społecznych, co pozwoli na ich rozwój i umożliwi poprawę innowacyjności i konkurencyjności (Mikołajczak, 2017).

Warto także dodać, że trudności przedsiębiorstw społecznych w pozyskiwaniu środków finansowych wynikają częściowo także z ich wizerunku. Z badań przeprowadzonych przez R. Batko i E. Bogacz-Wojtanowską (2015) wynika, że sfera działalności non-profit w Polsce postrzegana jest jako „słaba”, nieradząca sobie w tradycyjnych wolnorynkowych warunkach i oferująca pro- 


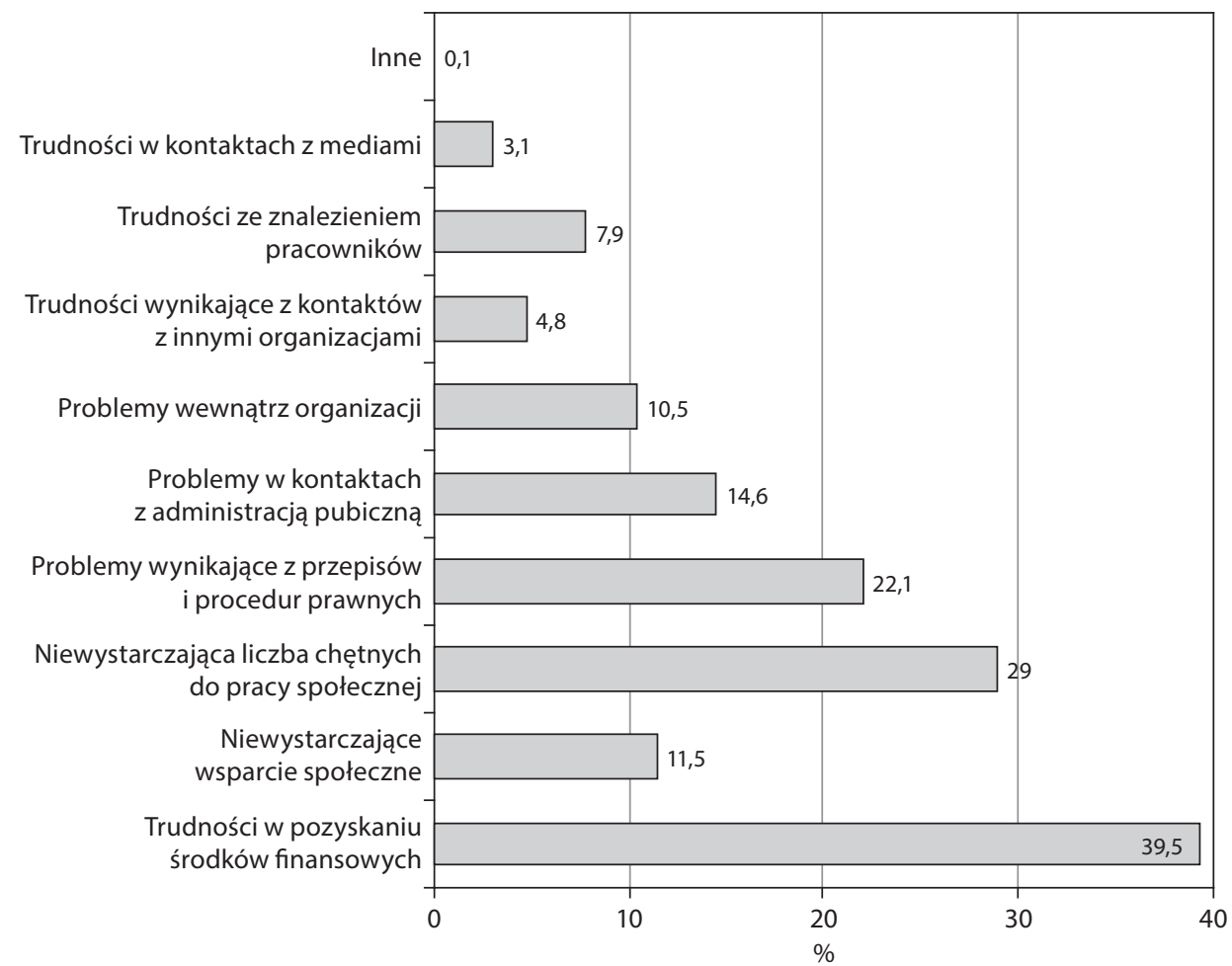

\section{Rysunek 1. Najpoważniejsze bariery w funkcjonowaniu podmiotów ekonomii społecznej} w Polsce w 2018 r. [w \%]

Źródło: opracowanie własne na podstawie danych Głównego Urzędu Statystycznego.

dukty i usługi gorszej jakości niż przedsiębiorstwa działające na zasadach komercyjnych. Takie skojarzenia mogą w praktyce stanowić poważne utrudnienie w pozyskiwaniu kapitałodawców.

W przytoczonych rozważaniach i badaniach kwestie finansowe są opisywane głównie w kontekście badań ankietowych czy też analiz teoretycznych i często odnoszą się do wybranych wątków i zagadnień ekonomiczno-finansowych Dlatego też w niniejszym artykule zdecydowano się przeprowadzić bardziej szczegółową i holistyczną analizę źródeł finansowania podmiotów ekonomii społecznej w Polsce. Jej wyniki stały się podstawą do zidentyfikowania dotychczasowych tendencji w zakresie finansowania przedsiębiorczości społecznej i sformułowania przewidywań odnośnie możliwości pozyskiwania przez nią źródeł finansowych w przyszłości.

\section{Metodyka badawcza}

Głównym celem prowadzonych rozważań i badań jest analiza źródeł finansowania podmiotów ekonomii społecznej w Polsce z perspektywy historycznej i prognostycznej (w kontekście kryzysu gospodarczego wywołanego pandemią Covid-19) oraz ocena możliwości rozwojowych tych podmiotów w fazie pokryzysowej. W ramach doprecyzowania tak określonego zakresu badań poszukuje się odpowiedzi na następujące problemy badawcze: 
- Jak zmieniała się w czasie liczba i struktura podmiotów ekonomii społecznej w Polsce w latach 2018-2020?

- Jakie źródła finansowania były wykorzystywane przez podmioty ekonomii społecznej w Polsce?

- Jak zidentyfikowane źródła finansowania będą się zmieniać w okresie kryzysowym i pokryzysowym i jak może to wpływać na rozwój przedsiębiorczości społecznej w Polsce?

By tak postawiony cel zrealizować, w pierwszej części badań odniesiono się do liczby i struktury podmiotów ekonomii społecznej w Polsce w latach 2012-2018. Następnie analizie poddano źródła ich finansowania. Na podstawie otrzymanych wniosków diagnostyczno-analitycznych sformułowano spostrzeżenia dotyczące uwarunkowań rozwojowych tych podmiotów w okresie kryzysowym i pokryzysowym. W badaniach posłużono się wskaźnikami struktury i dynamiki zjawisk i wykorzystano dane Głównego Urzędu Statystycznego na temat funkcjonowania organizacji non-profit w Polsce. Były to raporty pt. "Sektor non-profit" oraz sprawozdania nt. „Działalność stowarzyszeń i podobnych organizacji społecznych, fundacji, społecznych podmiotów wyznaniowych oraz samorządu gospodarczego i zawodowego opublikowane w latach 2016-2019". W celu zapewnienia porównywalności czasowej i podmiotowej w badaniach uwzględniono podmioty wykazywane w ramach wymienionych raportów i sprawozdań, co niewątpliwe ograniczyło zakres prowadzonej analizy, ale pozwoliło zachować jednoznaczność i przejrzystość prowadzonych badań statystycznych.

\section{Rozwój przedsiębiorczości społecznej w Polsce w latach 2012-2018}

Jak już wspomniano, w pierwszym etapie badań analizie poddano liczbę i strukturę podmiotów ekonomii społecznej w Polsce w latach 2012-2018. W grupie tych podmiotów wyróżniono następujące formy organizacyjnoprawne (Herbst, 2008; Pacut, 2010):

- stowarzyszenia, w tym stowarzyszenia sportowe, ochotnicze straże pożarne i koła łowieckie,

- fundacje,

- społeczne podmioty wyznaniowe,

- samorząd społeczny i gospodarczy.

Zmiany w liczbie wyżej wymienionych podmiotów przedstawiono na rysunku 2, a ich strukturę $w$ tabeli 1. Zgodnie $z$ danym zaprezentowanymi na rysunku 2, najpopularniejszą formą prowadzenia działalności w sektorze ekonomii społecznej w Polsce były i są stowarzyszenia. Ich liczba w analizowanym okresie wahała się od 69 do prawie 74 tysięcy. Popularność tej formy organizacyjnej wynika z względnej prostoty prowadzenia działalności, samorządności członków reprezentujących stowarzyszenie oraz możliwości pozyskiwania środków w formie składek członkowskich, co znacznie ułatwia prowadzenie działalności statutowej. Nie bez znaczenia jest w tym przypadku także dowolność celów powoływania stowarzyszeń. Obowiązujące aktualnie przepisy prawa (Prawo o stowarzyszeniach) pozwalają stowarzyszeniom dobrowolnie i samodzielnie kształtować zakres prowadzonej działalności oraz jej kierunki.

Fundacje, zdecydowanie mniej licznie reprezentowane w badanej grupie (8,5-14,5 tys.), nie zrzeszają członków, nie mają więc możliwości pozyskiwania składek członkowskich i wykorzystywania ich jako źródła finansowania. Ich cel jest także wyraźnie sprecyzowany prawnie (Ustawa o fundacjach). Powinien być społecznie lub gospodarczo użyteczny, zgodny z podstawowymi interesami Rzeczpospolitej Polskiej w szczególności takim jak: ochrona zdrowia, rozwój gospodarki i nauki, oświata i wychowanie, kultura i sztuka, opieka i pomoc społeczna, ochrona środowiska oraz opieka nad zabytkami. Powyższe okoliczności komplikują fakt pro- 


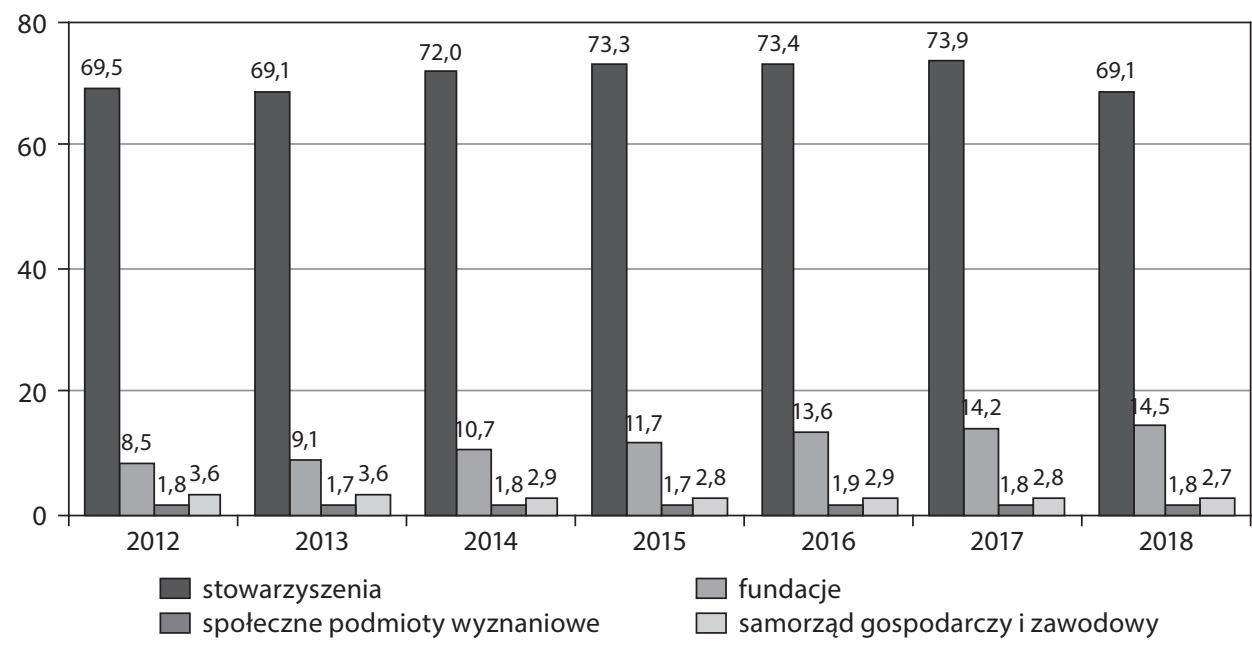

Rysunek 2. Liczba podmiotów ekonomii społecznej w Polsce w latach 2012-2018 [w tys.]

Źródło: opracowanie własne na podstawie danych Głównego Urzędu Statystycznego.

Tabela 1. Struktura podmiotów ekonomii społecznej w Polsce w latach 2012-2018

\begin{tabular}{|l|c|c|c|c|c|c|}
\hline \multirow{2}{*}{\multicolumn{1}{c|}{ Forma organizacyjna }} & \multicolumn{6}{c|}{ Lata } \\
\cline { 2 - 7 } & 2012 & 2013 & 2014 & 2015 & 2016 & 2017 \\
\hline Stowarzyszenia & $83,33 \%$ & $82,75 \%$ & $82,38 \%$ & $81,90 \%$ & $79,96 \%$ & $79,72 \%$ \\
\hline Fundacje & $10,19 \%$ & $10,90 \%$ & $12,24 \%$ & $13,07 \%$ & $14,81 \%$ & $15,32 \%$ \\
\hline Społeczne podmioty wyznaniowe & $2,16 \%$ & $2,04 \%$ & $2,06 \%$ & $1,90 \%$ & $2,07 \%$ & $1,94 \%$ \\
\hline Samorząd gospodarczy i zawodowy & $4,32 \%$ & $4,31 \%$ & $3,32 \%$ & $3,13 \%$ & $3,16 \%$ & $3,02 \%$ \\
\hline Razem & $100,00 \%$ & $100,00 \%$ & $100,00 \%$ & $100,00 \%$ & $100,00 \%$ & $100,00 \%$ \\
\hline
\end{tabular}

Źródło: opracowanie własne na podstawie danych Głównego Urzędu Statystycznego.

wadzenia fundacji i przyczyniają się do mniejszego zainteresowania tą formą wśród przedsiębiorców społecznych.

Społeczne związki wyznaniowe oraz samorząd gospodarczy i zawodowy stanowią najmniej liczne grono podmiotów działających w sferze ekonomii społecznej. Ich cele i zakres działalności są bardzo wąskie, bezpośrednio związane z danym wyznaniem, działalnością gospodarczą lub zawodem. Ich tożsamość jest zatem wyraźnie zdefiniowana i ograniczona, co w sposób naturalny wpływa na ich mniejsze znaczenie w sektorze ekonomii społecznej.

Warto w tym miejscu odnieść się również do głównych obszarów działalności statutowej czy regulaminowej podmiotów ekonomii społecznej w Polsce. Do najpopularniejszych z nich należą:

- sport, rekreacja, hobby,

- ratownictwo,

- pomoc humanitarna i społeczna,

- kultura i sztuka,

- edukacja i wychowanie, badania naukowe,

- ochrona zdrowia. 
Zgodnie z powyższym, w Polsce przedsiębiorczość społeczna pojawia się sferze dóbr uważanych za społeczne lub publiczne, służących zaspokajaniu potrzeb zbiorowych i często niewystarczająco dotowanych w ramach finansów publicznych czy lokalnych.

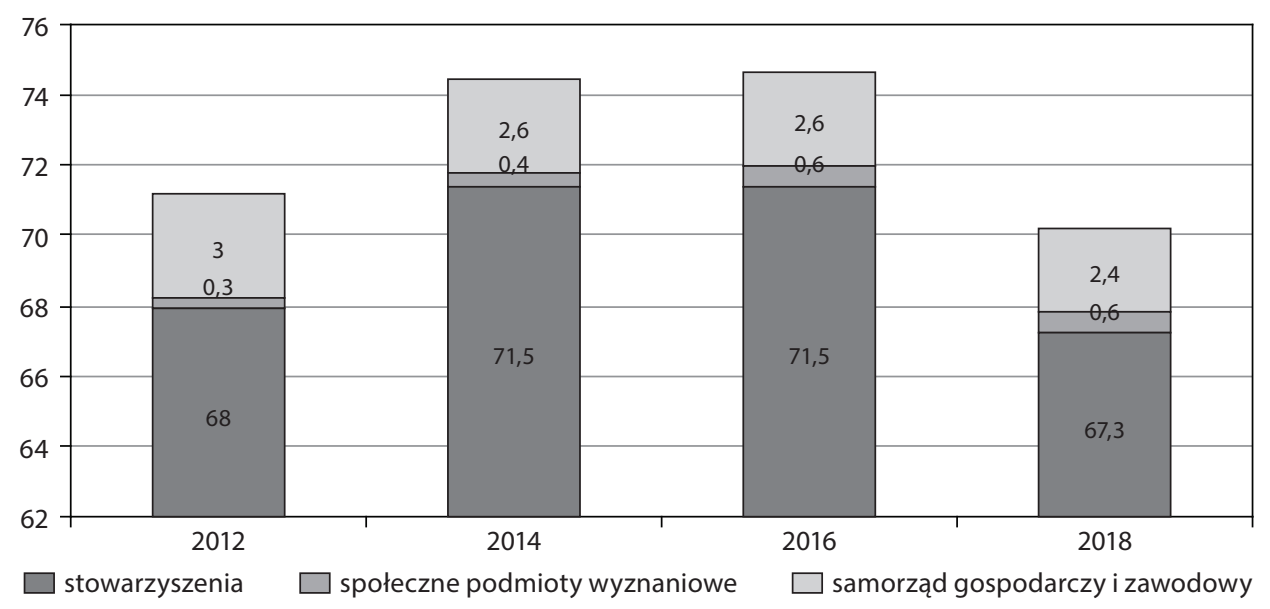

Rysunek 3. Liczba członków w poszczególnych formach organizacyjnych ekonomii społecznej w Polsce w latach 2012-2018 [w mln zł]

Źródło: opracowanie własne na podstawie danych Głównego Urzędu Statystycznego.

Odnosząc się do zmian liczby badanych podmiotów w analizowanym okresie, można było zauważyć systematyczny i dość znaczny wzrost liczby fundacji. Do 2017 wzrastała także liczba stowarzyszeń. Taka tendencja rozwojowa świadczy o wzroście zainteresowania działalnością społeczną, a tym samym rozwoju przedsiębiorczości społecznej w Polsce w ujęciu historycznym. Najprawdopodobniej przyczynił się do niej wzrost świadomości problemów społecznych oraz poprawiający się status życia polskiego społeczeństwa. Zaspokojenie najpilniejszych potrzeb bytowych i osiągnięcie satysfakcjonującego poziomu dobrobytu z reguły sprzyja bowiem poszukiwaniu nowych wyzwań i niematerialnych sposobów samorealizacji. Potwierdzają to również dane dotyczące liczby członków stowarzyszeń i społecznych podmiotów wyznaniowych (rys. 3), ale tylko do 2016 roku. W kolejnych dwóch latach zmniejszyła się zarówno liczba stowarzyszeń, jak i ich członków, co z kolei może dowodzić pewnego nasycenia działalności w sektorze ekonomii społecznej i zniechęcenia dotychczasowych współtwórców tych form działalności do dalszego działania na rzecz problemów społecznych, tym bardziej, że największa redukcja zainteresowania dotyczy najprostszej i najpopularniejszej formy przedsiębiorczości społecznej.

\section{Finansowanie przedsiębiorczości społecznej w Polsce w latach 2012-2018}

Mimo spadku liczby stowarzyszeń w Polsce w 2018 roku, nie wpłynęło to negatywnie na wysokość finansowania tego typu organizacji społecznych. Co więcej, z danych przedstawionych na rysunku 3 wynika, że przychody stowarzyszeń wyraźnie wzrosły właśnie w 2018 roku (tab. 1). Podmioty te były zatem skuteczniejsze w pozyskiwaniu źródeł finansowania na prowadzenie podstawowej działalności. Systematycznie i dość intensywnie wzrastały także 


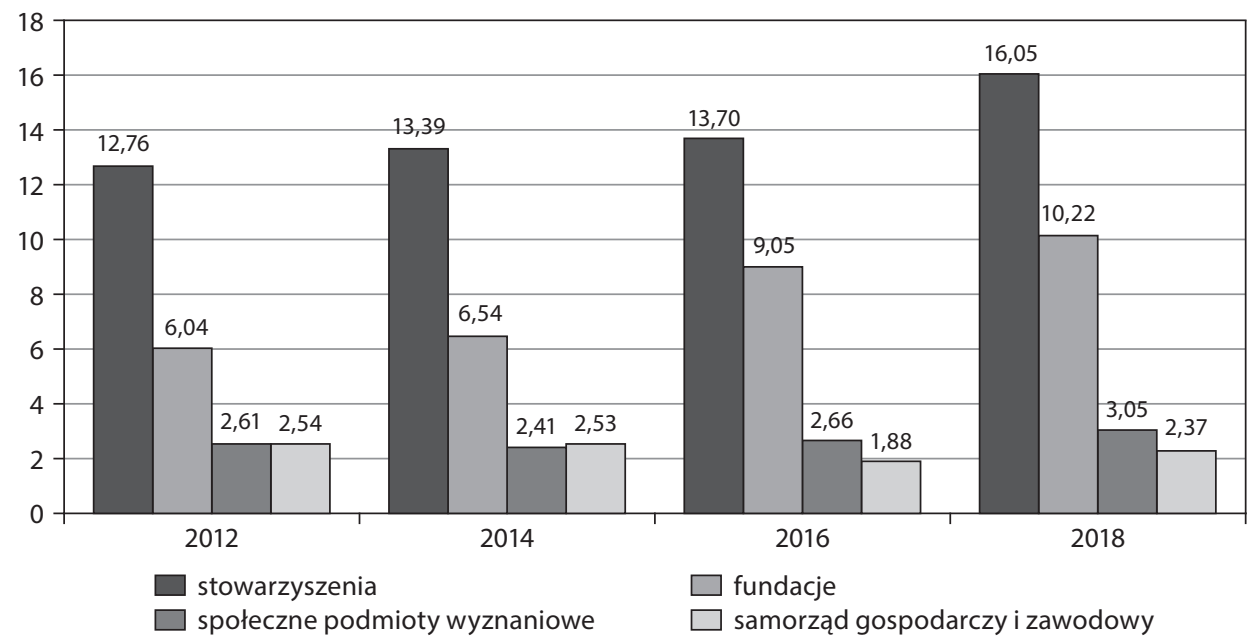

Rysunek 4. Przychody podmiotów ekonomii społecznej w Polsce w latach 2012-2018 [w mln zł]

Źródło: opracowanie własne na podstawie danych Głównego Urzędu Statystycznego.

Tabela 2. Struktura podmiotów ekonomii społecznej w Polsce w latach 2012-2018

\begin{tabular}{|l|c|c|c|}
\hline \multirow{2}{*}{\multicolumn{1}{c|}{ Forma organizacyjna }} & \multicolumn{3}{|c|}{ Lata } \\
\cline { 2 - 4 } & $2014 / 2012$ & $2014 / 2016$ & $2018 / 2014$ \\
\hline Stowarzyszenia & $4,99 \%$ & $2,30 \%$ & $17,18 \%$ \\
\hline Fundacje & $8,16 \%$ & $38,44 \%$ & $12,93 \%$ \\
\hline Społeczne podmioty wyznaniowe & $-7,58 \%$ & $10,19 \%$ & $14,90 \%$ \\
\hline Samorząd gospodarczy i zawodowy & $-0,37 \%$ & $-25,88 \%$ & $25,97 \%$ \\
\hline
\end{tabular}

Źródło: opracowanie własne na podstawie danych Głównego Urzędu Statystycznego.

przychody fundacji oraz społecznych związków wyznaniowych, co pozytywnie świadczy nie tylko o skuteczności zarządzających tymi podmiotami, ale daje również lepsze podstawy do intensywniejszej realizacji celów i szerszego zakresu działalności. Stwarza zatem korzystne warunki do rozwoju przedsiębiorczości społecznej. Wyraźny spadek liczby organizacji reprezentujących samorząd zawodowy i gospodarczy w 2014 roku (rys. 2) przyczynił się do zmniejszenia przychodów w tej grupie podmiotów. Niemniej w 2018 roku także samorządowi udało się zwiększyć wartość osiąganych przychodów, a tym samym możliwości działania.

Analizując strukturę przychodów w poszczególnych grupach podmiotów ekonomii społecznej odniesiono się do trzech najistotniejszych źródeł finansowania:

- przychodów rynkowych obejmujących: przychody z działalności gospodarczej, odpłatną działalność statutową, odsetki, dywidendy oraz przychody realizowane w ramach zamówień publicznych,

- przychodów nierynkowych obejmujących: zasilenia z centralnych i lokalnych środków publicznych, fundusze europejskie i inne fundusze zagraniczne, 1\% PIT oraz środki otrzymywane od osób i instytucji prywatnych w formie darowizn czy zbiórek publicznych,

- składki członkowskie. 
Udział wymienionych powyżej przychodów w źródłach finansowania poszczególnych podmiotów w latach 2012-2018 przedstawiono w tabeli 3.

Tabela 3. Struktura przychodów podmiotów ekonomii społecznej w Polsce w latach 2012-2018 [w \%]

\begin{tabular}{|c|c|c|c|c|}
\hline \multirow{2}{*}{ Rodzaj przychodów } & \multicolumn{4}{|c|}{ Lata } \\
\hline & 2012 & 2014 & 2016 & 2018 \\
\hline \multicolumn{5}{|c|}{ Stowarzyszenia } \\
\hline Rynkowe & $38,6 \%$ & $35,8 \%$ & $37,1 \%$ & $33,7 \%$ \\
\hline Nierynkowe & $53,3 \%$ & $55,7 \%$ & $51,5 \%$ & $55,7 \%$ \\
\hline Składki & $6,8 \%$ & $5,9 \%$ & $6,9 \%$ & $7,0 \%$ \\
\hline Inne & $1,3 \%$ & $2,6 \%$ & $4,5 \%$ & $3,6 \%$ \\
\hline Razem & $100,00 \%$ & $100,00 \%$ & $100,00 \%$ & $100,00 \%$ \\
\hline \multicolumn{5}{|c|}{ Fundacje } \\
\hline Rynkowe & $35,9 \%$ & $34,6 \%$ & $30,9 \%$ & $29,7 \%$ \\
\hline Nierynkowe & $62,2 \%$ & $64,4 \%$ & $65,3 \%$ & $66,6 \%$ \\
\hline Składki & $0,0 \%$ & $0,0 \%$ & $0,0 \%$ & $0,0 \%$ \\
\hline Inne & $1,9 \%$ & $1,0 \%$ & $3,8 \%$ & $3,7 \%$ \\
\hline Razem & $100,00 \%$ & $100,00 \%$ & $100,00 \%$ & $100,00 \%$ \\
\hline \multicolumn{5}{|c|}{ Społeczne podmioty wyznaniowe } \\
\hline Rynkowe & $40,3 \%$ & $37,0 \%$ & $40,7 \%$ & $35,2 \%$ \\
\hline Nierynkowe & $59,4 \%$ & $61,9 \%$ & $58,2 \%$ & $62,1 \%$ \\
\hline Składki & $0,1 \%$ & $0,5 \%$ & $0,1 \%$ & $0,1 \%$ \\
\hline Inne & $0,2 \%$ & $0,6 \%$ & $1,0 \%$ & $2,6 \%$ \\
\hline Razem & $100,00 \%$ & $100,00 \%$ & $100,00 \%$ & $100,00 \%$ \\
\hline \multicolumn{5}{|c|}{ Samorząd gospodarczy i zawodowy } \\
\hline Rynkowe & $56,3 \%$ & $59,2 \%$ & $59,0 \%$ & $55,5 \%$ \\
\hline Nierynkowe & $14,5 \%$ & $15,0 \%$ & $9,3 \%$ & $12,3 \%$ \\
\hline Składki & $26,7 \%$ & $24,2 \%$ & $29,6 \%$ & $29,1 \%$ \\
\hline Inne & $2,5 \%$ & $1,6 \%$ & $2,1 \%$ & $3,1 \%$ \\
\hline Razem & $100,00 \%$ & $100,00 \%$ & $100,00 \%$ & $100,00 \%$ \\
\hline
\end{tabular}

Źródło: opracowanie własne na podstawie danych Głównego Urzędu Statystycznego.

Głównym źródłem finansowania stowarzyszeń były przychody nierynkowe. Ich udział w strukturze finansowania niewiele zmieniał się w czasie i wynosił od 53\% do prawie $56 \%$. Były to głównie środki przekazywane przez samorządy lokalne oraz budżet centralny. Ich niewielkim uzupełnieniem były źródła unijne oraz 1\% PIT. Dość znacznym choć niedominującym uzupełnieniem przychodów stowarzyszeń były przychody rynkowe uzyskiwane przede wszystkim z działalności gospodarczej oraz odpłatnej działalności statutowej. Udział pozostałych przychodów rynkowych w postaci dywidend i odsetek nie przekraczał 2\%. Przychody stowarzyszeń były również zasilane w ramach składek członkowskich, co stanowiło około 6-7\% 
źródeł przychodów ogółem. Zgodnie z powyższym, stowarzyszenia były dość mocno uzależnione od publicznego wsparcia lokalnego i centralnego, a co za tym idzie ich samodzielność finansowa była i jest znacznie ograniczona. Uzależnienie to należy uznać za trwałe z uwagi na praktycznie niezmienną strukturę finansowania obserwowaną w całym analizowanym okresie obejmującym siedem lat.

Podobnie przedstawiała się hierarchia i struktura finansowania fundacji, w której jeszcze wyraźniej wyróżniała się dominacja źródeł nierynkowych, co było i jest spowodowane brakiem możliwości uzupełniania źródeł finansowania przez składki członkowskie. Przy czym w tym przypadku rola przychodów nierynkowych systematycznie rosła w czasie z uwagi na ich rosnący udział z 62,2\% w 2012 roku do 66,6\% w 2018 r. Warto jednak dodać, że wewnętrzna struktura przychodów nierynkowych fundacji była inna niż w miało to miejsce w przypadku stowarzyszeń. Fundacje w równiej mierze pozyskiwały środki nierynkowe z sektora publicznego i prywatnego. W sektorze publicznym dominujące wsparcie finansowe napływało ze strony samorządów lokalnych. W sektorze prywatnym środki nierynkowe pochodziły przede wszystkim z darowizn, co stanowi pewien finansowy i organizacyjny wyróżnik tej formy prowadzenia działalności w sektorze ekonomii społecznej. Z kolei na rynkowe przychody fundacji wynoszące około 30-36\% składały się w równej mierze przychody z działalności gospodarczej i przychody z odpłatnej działalności statutowej. Powyższe informacje świadczą o wyższej zależności fundacji od hojności darczyńców, jednakże zależność ta była bardziej zdywersyfikowana, ponieważ odnosiła się równomiernie do sektora publicznego i prywatnego.

Społeczne podmioty wyznaniowe, podobnie jak stowarzyszenia i fundacje, utrzymywały się głównie ze środków nierynkowych, które pochodziły przede wszystkim z lokalnych budżetów samorządowych. Ich uzupełnieniem były przychody nierynkowe z budżetu centralnego oraz darowizny. Udział przychodów rynkowych w źródłach finansowania tych organizacji wahał się do 35\% do prawie $41 \%$ i w dość równej proporcji składały się na niego środki pozyskiwanej w ramach prowadzonej działalności gospodarczej i odpłatnej działalności statutowej. Składki członkowskie i inne przychody nie miały większego znaczenia w finansowaniu działalności społecznych podmiotów wyznaniowych. Taka struktura finansowania, praktycznie niezmienna w czasie, wskazuje na znaczne uzależnienie od lokalnego finansowania publicznego. Jest ono jeszcze większe niż miało to miejsce w przypadku stowarzyszeń, które miały możliwość dodatkowych zasileń ze składek członkowskich. Można zatem stwierdzić, że zakres działania tych podmiotów był, jest i będzie skorelowany z sytuacją finansową jednostek samorządu terytorialnego, które istotnie dotują ich działalność.

Struktura finansowania samorządu gospodarczego i zawodowego była odmienna od opisanych powyżej, ponieważ wyraźnie dominowały w niej źródła rynkowe oraz składki członkowskie. Źródła rynkowe stanowiły głównie przychody z działalności gospodarczej, uzupełniane przez przychody z działalności wykonywanej odpłatnie. Takie ukształtowanie struktury finansowania wydaje się wynikać z trzech okoliczności. Po pierwsze, z większego doświadczenia zarówno zarządzających, jak i członków w zakresie prowadzenia odpłatnej działalności gospodarczej. Po drugie, z większej sieci kontaktów zawodowych i gospodarczych ułatwiających prowadzenie komercyjnej działalności gospodarczej. I po trzecie, z lepszej sytuacji dochodowej członków samorządów gospodarczych i zawodowych ułatwiającej systematyczne i efektywne pozyskiwanie składek członkowskich. W tym przypadku przychody nierynkowe, pochodzące przede wszystkim z budżetów lokalnych, stanowią jedynie uzupełnienie źródeł finansowania stanowiące od 9\% do 15\% źródeł finansowania ogółem. Oznacza to dużą niezależność i samodzielność finansową opisywanego typu organizacji. 


\section{Zakończenie}

Z przeprowadzonych analiz wynika, że w ujęciu historycznym przedsiębiorczość społeczna w Polsce rozwija się systematyczne, aczkolwiek wolno. Świadczy o tym rosnąca liczba podmiotów działających w sferze ekonomii społecznej, w tym przede wszystkim stowarzyszeń i fundacji. Wzrasta także liczba członków stowarzyszeń, społecznych podmiotów wyznaniowych oraz samorządów gospodarczych i zawodowych. Może to korzystnie rokować na przyszłość, w tym także tę związaną z kryzysem pandemicznym oraz fazą pokryzysową, tym bardziej, że znaczna część badanych organizacji deklaruje działalność w obszarze: ochrony zdrowia, ratownictwa, pomocy społecznej i humanitarnej, kultury i sztuki czy sportu, a więc w obszarach najmocniej dotkniętych skutkami pandemii.

Dobrym prognostykiem dla rozwoju polskiej przedsiębiorczości społecznej jest także powszechność i względna łatwość prowadzenia stowarzyszeń, najpopularniejszej formy działalności w ramach ekonomii społecznej. Dowolność celów, swoboda zakładania i działania oraz wspólnotowość, towarzyszące tej formie przedsiębiorczości, pozwalają na realizację wielu bardzo różnorodnych zamierzeń niekomercyjnych i umożliwiają samorealizację wszystkim jej członkom.

Zakładanie i prowadzenie działalności fundacji może stanowić z kolei bardziej ambitne wyzwanie dla wszystkich tych obecnych i potencjalnych przedsiębiorców społecznych, którzy oczekują większej niezależności oraz sprawczości działań podejmowanych na rzecz niekomercyjnego rozwiązywania problemów społeczno-gospodarczych. Rosnąca liczba tego typu podmiotów w analizowanym okresie pozwala domniemywać, że ich istnienie i powstawanie jest odpowiedzią na realne potrzeby indywidualne i zbiorowe, których zakres i intensywność w okresie pandemii znacząco wzrosły.

W świetle powyższego można stwierdzić, że analiza dotychczasowych tendencji rozwojowych pozwala optymistycznie spojrzeć na szanse na kryzysowy i pokryzysowy rozwój przedsiębiorczości społecznej. Niestety tym, co może je poważnie ograniczyć są możliwości finansowe podmiotów działających w sferze ekonomii społecznej. Z przeprowadzonych analiz wynika bowiem, że działalność fundacji, stowarzyszeń i społecznych związków wyznaniowych była w dużej mierze uzależniona od środków pozyskiwanych z lokalnych i centralnych źródeł budżetowych. Obecny kryzys gospodarczy, a także faza pokryzysowa nieuchronnie wiążą się z obniżeniem wpływów w tych budżetach, a co za tym idzie także z redukcją wydatków na dofinansowywanie badanych organizacji. W konsekwencji może to przyczynić się do ograniczenia lub nawet likwidacji ich działalności.

Problemem może być także pozyskiwanie składek członkowskich z uwagi na utratę lub zmniejszenie dochodów osób fizycznych i prawnych, a to z kolei może powodować zmniejszenie źródeł finansowania w przypadku samorządów gospodarczych i zawodowych oraz stowarzyszeń. Z kolei w przypadku fundacji taka pauperyzacja może niekorzystnie oddziaływać na poziom darowizn, jednego z głównych przychodów tych instytucji.

W związku z powyższym przed przedsiębiorczością społeczną w Polsce stoi trudniejsze niż dotychczas zadanie pozyskania środków finansowych na działalność statutową i regulaminową. W sytuacji kryzysu dotykającego sferę publiczną i prywatną dopływ finansowania kurczy się ze zdwojoną siłą, co z pewnością nie zahamuje, ale może ograniczyć powstawanie i zakres działalności podmiotów ekonomii społecznej. 
Z dotychczasowych badań krajowych i zagranicznych wynika szereg rekomendacji, które mogą być pomocne przy wspieraniu podmiotów ekonomii społecznej w Polsce, w tym także w fazie pokryzysowej. Można do nich zaliczyć między innymi:

- podejmowanie działań na rzecz poprawy wizerunku przedsiębiorczości społecznej wśród potencjalnych kapitałodawców poprzez działania promocyjne i edukacyjne,

- udzielanie wsparcia formalno-prawnego w procesie pozyskiwania źródeł finansowania, w tym w szczególności w odniesieniu do partnerstwa publiczno-prywatnego oraz funduszy Unii Europejskiej,

- prowadzenie akcji informacyjnych dotyczących pożytków wynikających z ekonomii społecznej i zachęcających do jej finansowania,

- wzmocnienie ochrony i pomocy prawnej w obszarze ochrony własności intelektualnej i przemysłowej.

\section{Literatura}

Augustyniak, P., Ciesiołkiewicz, K., Dudkiewicz, I., Fandrejewska, A., Gąciarz, B., Obracht-Prondzyński, C., Pacut, A., Przedlacki, M., Sadzik, J., Tarkowski, A., Wygnański, K. (2020). Alert Społeczny 1: Ratujmy najsłabszych, bądźmy wspólnotą. Open Eyes Economy Summit, 1, https://oees.pl/wp-content/uploads/2020/04/Alert-Spo\%C5\%82eczny-1-OEES.pdf

Bartkowski, J. (2014). Solidarność społeczna i kryzys: Zmiany wartości w Europie i w Polsce w warunkach kryzysu. Acta Universitatis Lodziensis. Folia Sociologica, 48, 19-34.

Batko, R., Bogacz-Wojtanowska E. (2015). Przedsiębiorstwa społeczne - poszukiwanie tożsamości pomiędzy celami ekonomicznymi a społecznymi. Problemy Zarządzania, 13(4), 195-206.

Defourny J., Nyssens M. (2010). Conceptions of social enterprise and social entrepreneurship in Europe and the United States: Convergences and divergences. Journal of Social Entrepreneurship, 1(1), 32-53.

Ekonomia społeczna w Polsce w nowej perspektywie finansowej 2020+. Wnioski i rekomendowane rozwiazania. https://www.ekonomiaspoleczna.gov.pl/download/files/EKONOMIA_SPOLECZNA/ES_2021_2027_streszczenie.pdf

Gramescu, L. (2016). Scaling Social Innovation in Europe: An Overview of Social Enterprise Readiness. Procedia Social and Behavioral Sciences, 221, 218-225.

Gabriel, M (2014). Making it big: Strategies for scaling social innovations. London: Nesta.

Goyal, L. (2020). Exploring frugal innovation in social entrepreneurship:: Insights from emerging economies. Organizational Dynamics, 100782, https://doi.org/10.1016/j.orgdyn.2020.100782

Hausner J., Laurisz N. (2006). Czynniki krytyczne tworzenia przedsiębiorstw społecznych. Przedsiębiorstwo społeczne. Konceptualizacja. W: Przedsiębiorstwa społeczne w Polsce. Teoria i praktyka. Kraków: Małopolska Szkoła Administracji Publicznej Uniwersytetu Ekonomicznego w Krakowie.

Hausner J. (2009). Ekonomia społeczna jako kategoria rozwoju. W: J. Hausner (red.). Ekonomia społeczna a rozwój. Małopolska Szkoła Administracji Publicznej. Wydawnictwo UE w Krakowie: Kraków 2009.

Herbst, J. (2008). Pole przedsiębiorczości społecznej w Polsce. W: J. Hausner, A. Giza-Poleszczuk (red.). Ekonomia społeczna w Polsce: osiagnięcia, bariery rozwoju i potencjał w świetle wyników. Warszawa: Fundacja Inicjatyw Społeczno-Ekonomicznych.

Kaufman, R., Avgar, A., Mirsky, J. (2015). Opportunities for sustainable community development in the wake of disaster situations: Lessons from the field. International Journal of Sustainability Policy and Practice, 11(2), $1-10$.

Kaufman, R., Mirsky, J., Avgar, A. (2007). Social Entrepreneurship in Crisis Situations. International Journal of Diversity in Organizations, Communities and Nations, 7(3), 227-232.

Kerlin, J. (2006). Social enterprise in the United States and Europe: Understanding and learning from the differences. Voluntas, 17(3), 247-263.

Mair J., Martí I. (2006). Social entrepreneurship research: A source of explanation, prediction, and delight. Journal of World Business, 41, 36-44.

Mikołajczyk, P. (2017). Współczesne wyzwania nowej ekonomii społecznej. Zeszyty Naukowe Polskiego Towarzystwa Ekonomicznego w Zielonej Górze, 7, 237-249. 
Leś, E. (2005). Nowa ekonomia społeczna. Wybrane koncepcje. Trzeci Sektor, 2. Warszawa: Fundacja Instytutu Spraw Publicznych.

Łojko, M. (2017). Ekonomia społeczna wobec wyzwań polityki społecznej - w poszukiwaniu wspólnych relacji i przestrzeni. Kwartalnik Kolegium Ekonomiczno-Społecznego Studia i Prace, 3, 31-49.

Pacut A., (2010). Przedsiębiorczość społeczna w Polsce - problemy i wyzwania. Zarzq̨dzanie Publiczne, 4(14), s. $45-57$.

Płonka, M. (2015). Ekonomia społeczna a koncepcje polityki społecznej państwa. Model polski, Ekonomia Spoteczna, 2, 85-100.

Rechulicz, M. (2006). Organizacje pozarządowe - alternatywa dla przedsiębiorczości czy przedsiębiorczość? Trzeci Sektor, 7.

Romanowska, M. (2016). The Evolution of the Strategic Goals of Polish Enterprises During the Economic Crisis. Journal of Management and Financial Sciences, 24(9), 13-26.

Sienkiewicz-Małyjurek, K. (2015). Skuteczne zarzadzanie kryzysowe. Warszawa: Difin.

Tarkowski, A. (2020). Społeczeństwo coraz bardziej open source'owe [Ngo.pl]. Jak COVID-19 zmieni Polskę. Prognoza liderów polskich środowisk branżowych i społecznych. https://publicystyka.ngo.pl/jak-covid-19zmieni-polske-prognoza-liderow-polskich-srodowisk-branzowych-i-spolecznych

Weber, C., Kröger, A., Lambrich, K. (2012). Scaling Social Enterprises-A Theoretically Grounded Framework. Frontiers of Entrepreneurship Research, 32(19), 3-5.

Vanderhoven, E., Steiner, A., Teasdale, S., Calò, F. (2020). Can public venture capital support sustainability in the social economy? Evidence from a social innovation fund. Journal of Business Venturing Insights, 13, https:// doi.org/10.1016/j.jbvi.2020.e00166

Zioło, Z. (2013). Uwarunkowania rozwoju przedsiębiorczości w warunkach kryzysu gospodarczego. Przedsiębiorczość-Edukacja, 9, 10-33.

\section{Financing of social economy entities and the development of social entrepreneurship in Poland. Pre-pandemic crisis conclusions and post- pandemic crisis reflections}

Summary: The development of social entrepreneurship is associated with many barriers of various nature. One of the most serious is the lack of financial resources, which becomes particularly acute and troublesome in times of economic crisis. Considering the above circumstances, the main goal of the considerations and research conducted in this article is to identify the directions of development of social economy entities in Poland and to analyze the sources of financing their activities from a historical and forecasting perspective (in the context of the economic crisis caused by the Covid-19 pandemic). In order to achieve this goal, the article uses a statistical analysis of data on the sources of financing of social economy entities in Poland. The conducted analyzes show that, historically, social entrepreneurship in Poland was systematically, but slowly, developing. This is evidenced by the growing number of entities operating in the field of the social economy, including primarily associations and foundations. However, this development is currently threatened due to the reduction of revenues in the public sphere, which are the main source of income for the surveyed organizations. In the near future the problem may also be obtaining membership fees which are a supplementary source of financing for social entrepreneurship.

Keywords: social entrepreneurship; social economy; financing social entrepreneurship

JEL codes: H0O; A32; A13

\section{Informacje o autorce}

\section{Izabela Jonek-Kowalska, prof. PŚ dr hab.}

ORCID: 0000-0002-4006-4362

Katedra Ekonomii i Informatyki

Wydział Organizacji i Zarządzania

Politechnika Śląska

ul. Roosevelta 26-28, 41-800 Zabrze

e-mail: izabela.jonek-kowalska@polsl.pl

Źródło finansowania badań: Źródłem finansowania badań jest część badawcza subwencji przyznanej Katedrze Ekonomii i Informatyki, Wydział Organizacji i Zarządzania, Politechnika Śląska: BK 235/ROZ 1/2020. 


\section{Prawa autorskie i licencja / Copyright and License}

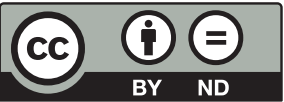

Publikacja na licencji Creative Commons Uznanie autorstwa Użycie niekomercyjne - Bez utworów zależnych 4.0 Międzynarodowe (CC BY-ND 4.0) http://creativecommons.org/licenses/by-nc-nd/4.0/deed/pl

This work is published under the terms of the Creative Commons

Attribution - NoDerivetives International (CC BY-ND 4.0) License http://creativecommons.org/licenses/by-nc-nd/4.0

Wydane przez Uniwersytet Ekonomiczny w Krakowie. Małopolska Szkoła Administracji Publicznej

Published by Cracow University of Economics - Krakow, Poland. Małopolska School of Public Administration of the Cracow University of Economics 